\title{
Feminism as Epistemic Disobedience and Transformative Knowledge: Exploration of an Alternative Educational Centre
}

\author{
Biljana Kašić, University of Zadar, Zadar, Croatia (retired)
}

\section{Introductory Note: Difficulties}

W

hile approaching the issue of non-institutional education in terms of feminism nowadays for this article, I must admit I felt quite uncomfortable, even anxious, for several reasons. First, the commitment made in this type of education cannot be measured at the level of type of institutional education but assumes a full socio-bodily engagement, meaning the deep embeddedness of all subjects in the entire process. Moreover, it is governed by ideals which, by critically analysing that very education, require a distinct ethico/political/theoretical stance coupled with emancipatory educational politics as the ultimate foundation. Second, given that the feminist "we", namely the status of the subject of feminism lying at the core of this type of education, now finds itself under the serious threat of many current overlapping forces, we are facing new modes of exclusions to attaining subjectivity and agency while questions of what these categories mean have become more fragile and more difficult. Finally, what is the main objective of the Centre for Women's Studies in Zagreb in continuing with alternative education if it cannot challenge the mainstream education in the full sense of that word, namely when its transformative effects have consistently been ignored, 'neutralised' or even disrupted by many factors, especially during the last few years. We are now witnessing various obstructive contextual moments (neoliberal politics, market-oriented academy, neo-conservative movement, retrograde backlash trends, among others) on both the global and local levels as well as new-old prejudices with respect to feminist epistemology, disciplines and education. 
At one moment, I felt like giving up on yet another attempt at analysing what this is all about and taking refuge in feminist scepticism, but I resisted. There is no possibility of any pulling back, not anymore.

\section{Promising Entry}

I recently reread Nora Sternfeld's article “Unglamorous Tasks: What Can Education Learn from its Political Traditions?" (Sternfeld, 2010), which fully reinvigorated my previous ideas on how alternative education might look like, emboldening me to create the grounds for exploring the role of women's studies education in the current and quite specific historical and cultural context. It also enabled me to help move in this direction, despite some inner reluctance and sites of resistance. Instead of promoting certain nationally-oriented goals, culture and values or reproduction of knowledge as embedded in the traditional tasks of education, Sternfeld opted for another intention of education. In her view, education is " /... about exploring the possibilities of an alternative production of knowledge that resists, supplements, thwarts, undercuts, or challenges traditional forms of knowledge" (Sternfeld, 20Iо, p. r).

Sternfeld elaborated her critical ideas while rethinking the traditions of political education via examples of the role of Left protagonists (Walter Benjamin, Edwin Hoernie, Bertolt Brecht) in the Germany of the Weimar Republic and their ideas on "communist pedagogy" and "teaching play" methods, then with regard to the "pedagogy of the oppressed" and "liberation pedagogy" first developed by the Brazilian theologian Paulo Freire, and further elaborated by Peter Mayo, as well as more recent radical, feminist and antiracist education (Henry A. Giroux, bell hooks) from the 1960 s onwards. By using this historical trajectory of critical ideas and practices, she wanted to explain not only which educational techniques have guided towards progressive tasks within twentieth-century (post)-modernity, but why we need a politicality of education nowadays.

My analysis somehow emerges as a productive response to some of the theses set out in this article. Three postulates from Sternfeld's text are relevant here: first, there is no neutral education while dealing with specific conditions and contingencies as well as with one's own experiential gesture; second, education is the very process of taking a stand that both dismantles the traditional educator/learner (subject-object) relationship and urges for emancipatory action; third, "there is always something unforeseeable in education" (ibid., p. 5) that sheds more light on the entire process, making it exciting, unpredictable and uncontrollable. 


\section{The Centre for Women's Studies Zagreb: Contexts, Questions, Desires}

Rather than attempting to explore the above-mentioned postulates in any well-ordered manner, I instead wish to focus on certain issues they trigger and imbue and which I see as significant for feminist alternative education. By using the Centre for Women's Studies in Zagreb/Croatia as an example, I argue that an alternative form of education outside of academic institutions can ensure a freeing up from hegemonic and misogynist knowledge more than the mainstream one, above all by creating a powerful shift towards feminism as an epistemic disobedience and activist theory. Thereby, the issue of feminism as epistemic disobedience and activist theory is not the point of departure in my analytical task, but one of the most vitalising impulses of feminist scholarship aiming for transformative knowledge.

Before moving deeper to explore its modes and effects, some facts need to be noted to analyse this specific feminist education programme. Founded 25 years ago, the Centre for Women's Studies was the first and today still is the only place offering an interdisciplinary and comprehensive programme in women's/feminist studies in Croatia. Run by feminists, namely scholars, artists, and women with experience in women's and civil activist work, the programme throughout all these years has been created and performed using its own model, content and tools. Through a wide range of ingeniously conceptualised modules/courses/workshops/actions, it offers students innovative multi- and interdisciplinary education based on critical pedagogy and continuous self-experimenting approaches and perspectives (Kašić, 2016). More precisely:

In the conceptual-epistemological sense, the contents of the educational program are at one level interdisciplinary and connected multitextually, on another level they become intertwined with experiential knowledge, while courses, modules and seminars, with few exceptions, function more as 'thematic studies', and less as studies of the disciplines viewed from a women's/gender perspective (Barada et al., 2003, p. I2I).

Over the whole time, it has been designed as an open model of education that entails an immensely inspiring programme based on the theoretical articulation of feminism and feminist experience, feminist pedagogy and experiential learning styles, personal expressiveness and art. Along with developing its own education matrix, the idea of the Centre has always been to provide its students with a motivating space for creative learning and personal "growth". In short, the Women's Studies education programme was primarily conceptualised as a critical reading of various fields of scholarly work, reality, iconography, literature, the media, visual 
signs, body, stereotypes etc. through multiple exchanges, as well as consciousness-raising studies to a certain extent.

Despite facing many changes (educational, intergenerational, from women-only to queering students, among others) and obstacles (structural, political, financial etc.), the Centre has persisted in its mission to affirm feminism as an indisputable knowledge claim. By carrying out the education at the crossroads of disciplines (humanities and social sciences, but also natural sciences), artistic practices and activism, it has attempted to see which feminist ideas circulate across them and what are the ranges of their influence and shifts. While in 1995, in the context of (post)war conflicts and dissolution of the union of Yugoslav states, the Centre took on feminist theory as a critical tool against the nationalistic ideology and the war paradigm, then acting as a kind of ethical survival, nowadays there are other questions and motives that matter.

How can we invent new feminism(s) as an emancipatory promise once more, as a radical discourse that works against inequalities, the subjugation of women, and impediments to freedom while confronting neoliberalism and "neoliberalising feminism" (Prügl, 20I5)? Since "the neoliberal trend is impregnated /.../ with old fashioned academic design that counts on (neo)conservativism" (Kašić, 2016, p. 130), retrograde paths and (neo)traditional morality, how can we then respond to the sexist, androcentric, anti-gender and racist assumptions that deepen inequality and foster social exclusion and discrimination? How can we through feminist lenses at the same time reflect upon topics that include the state of critical approaches to rights, discriminatory practices and injustice, and endeavour to create epistemological alliances with critical studies such as decolonial or antiracist research studies, among others? Also, how can we re-posit the role of feminist agency in a post-(neo)Marxist, post-(neo)colonial, and postmodern epistemological context in order to affirm the feminist struggle and transnational solidarity across the borders (Mohanty, 2003)? These are some of the urgent issues that require careful attention for analysis. Finally, which radical interventions are needed in feminist education in order to respond to these on-going demands?

\section{Feminism as Subversive Knowledge: A Troubling Setting}

/.../ feminism as an epistemological project is /... / a struggle for meaning, for concepts, for the tradition of thought. It is an oppositional, potentially (subversive) knowledge that challenges the ruling ideas, questions the literary, philosophical, historical canon, transforms "official knowledge" 
and, in short, calls into question everything that is taught at universities (Bahovec, 2002, p. 23).

Almost two decades ago, the Slovenian theorist Eva Bahovec made the above statement about feminism, which in my view is more than relevant here. This concerns the radical deconstruction of the entire tradition of thinking "inside", or what is considered to be "official" (male, heteronormative, universal) knowledge, along with creating the foundations for a new tradition at the threshold of the epistemologisation of the concepts of "absence" and (female) Other, and the (feminist) theory that it has incited.

When thinking about feminist knowledge within the educational institutional frame, the whole issue takes on a new problematic dimension. While agreeing with Mary Evans's statement that in the meantime "feminism has achieved at least partial academic recognition" (Evans, 2003, p. I5), it is still unclear to what extent this recognition assumes feminism's subversive and counter-canon potential. Namely, just the fact that, as Bahovec rightly considered, the potentially subversive knowledge that is that distinct feature the epistemic status of feminism makes specific at the same time provides for a continuous tension between feminism and its academic verification. On one hand, feminism means permanent questioning and challenging the foundations and canons of official knowledge across various disciplines, while on the other it constructs a space for its more viable basis and acknowledgement. This means both adding new contents into existing scientific disciplines and embedding a gender perspective across the curriculum as well as introducing different epistemological and analytical tools as its feminist standpoint theory, for example (Smith, 1987; Harding, 2004; Hill Collins, 2009). Starting from the premise that knowledge is always socially situated and that women's lived experiences are crucial for any scientific enquiry, this approach over the last few decades has introduced critiques of the relationship between material experience, power and epistemology that in various ways have influenced the production of knowledge.

Since neoliberal trends in conjunction with scientific backlash have in many respects shifted the university's role in the direction of a managerial and almost tedious institution (Butler \& Athanasiou, 2013; Alvanoudi, 2009), along with changing the existing disciplines, imposing new curricula, and diminishing their critical stimulus, feminist scholars are confronting new-old obstacles and hostility to feminism. The main question today is not whether the academic community is willing to fully allow a counter-hegemonic scientific narrative such as feminism into 
its cognitive and educational texture, but how and whether at all feminism itself resonates with this type of academy and marketability-oriented knowledge in particular.

Going back to Bahovec's key argument on feminism as being oppositional, namely subversive knowledge, we can see two evident tendencies in the Croatian academic framework which are quite opposite from the feminist drive. In addition to systematically excluding or reducing educational subjects with a clear feminist agenda at Croatia's universities over the last decade, on-going "disciplining" disciplines are in place. Central to the latter point, a hybrid type of bureaucratic-disciplinary surveillance has been established, by governing the scientific disciplines and their educational curriculum it insists on a "purity" of disciplines, namely the centring of scientific disciplines around their core subject and methodological axis (Kašić, 20II). Maria do Mar Pereira (2017) quite clearly noted that we should deal with the mainstream knowledge of scientificity while women's, gender, feminist studies (WGFS) "is not quite proper academic knowledge" (Pereira, 2017, p. I) One consequence of this process is concealing, misusing or giving up the interdisciplinarity that is dramatically changing educational settings (Hemmings, 2008; Liinason \& Holm, 2006).

An emerging question here then is what is the place for feminism and critical pedagogy within this educational framework? While the situation within the university is not promising for either the epistemic status of Women's/Gender Studies ${ }^{1}$ or feminism as a theoretical or activist 'project' that reflects processes in academia worldwide, alternative education seems like the only desirable place or, better, a theoretical "asylum" for experimenting, self-reflecting and subverting self-evident clichés and canons of knowledge production as well as a different entry into feminism.

In the research project on women's studies education at the Centre for Women's Studies, whose results were published in the book Privilegiranje rubova. Intervencije i prilozi feminističkoj epistemologiji / Privileging the Margins. Interventions and Contributions to Feminist Epistemology/ (Čakardić et al., 2010), students of Women's Studies frequently identify it

One of the paradoxes concerning Women's/Gender studies in the Croatian Academy is that Gender Studies is entered in the scientific categorisation of programmes recognised by the National Council for Science (in 2009 it was classified as an interdisciplinary field of science; source: "Ordinance on scientific and artistic areas, fields and branches", from 22. 09. 2009), despite the fact that neither Gender nor Women's Studies as an integral field of knowledge has become a part of the academic curricula in Croatia. It should be noted that this initiative for verifying Gender Studies as an academic field came from the Centre for Women's Studies in collaboration with the Department of Ethnology and Cultural Anthropology, Faculty of Humanities and Social Sciences in Zagreb. 
as a "safe place" ("oasis", "shelter", “comfortable women's club”) in which the notion of security is translated into a "different kind of space", also understood as an "alternative" space as well as an epistemologically new space.

Here I cite an example from an interview with one of the students:

Women's Studies epitomised a "safe", different intellectual, emotional, conceptual, cognitive space. A different way of knowing. A space in which one could "extend" in an unconventional or conventional direction without fear or disparagement. Suddenly, what I was feeling was legitimate, and not (only) that what could be gauged. /.../ It was unusually important to know, to discover that what I perceived as me could be completely epistemologically legitimate (excerpt from an interview with a Women's Studies student, generation 2006/2007).

As may be seen from the above excerpt, the space for feminist teaching means a safe place for articulating the self, which is a prerequisite for learning feminism and for the mutual exchange of ideas and thoughts. For bell hooks, the politics of location is inseparable from the politics of knowledge and the politics of resistance, and both derive their meanings from theorising about the experience of transformation and the art of creating new knowledge, which is essentially a "plan for radical critical practice" (hooks, 1996, p. 5i).

In her essay "Rethinking the Time of Feminism", Drucilla Cornell states: "Feminism is radical because it demands that we re-think the 'origins' and the 'limit' of philosophical discourse, even as we are challenged to do so philosophically" (Cornell et al., I995, p. I49).

Here, I would like to elaborate more on the potential held by disobedience while remaining in the terrain of feminist epistemology. Bearing in mind all of its above philosophical foundations, I felt somewhat uneasy with the notion of epistemology firstly due to its discursive pretension to embrace totality or wholeness in terms of knowing, marked as "universal". The inability of recognising examples of misogyny in science or humanities, or the sexism that thus institutionalises the inferiority of women in discourse through epistemic operability, refers to the historical refusal to unfold the knowledge formatted within hegemonic universal epistemology. The more I dealt with feminist epistemology, the more I found its subversive potential for creating some of my arguments around justifying feminist claims for recognition and re-appropriation of the notions and concepts which have been stolen from women. Questioning concepts such as gender/sex differences, discrimination, misogyny, cognitive biases and sexism, domination and colonisation, the relations of sexual identity 
and dominant matrices in knowledge, even though it causes anxiety and distress, and often anger and resistance, is the demand of feminist epistemology. In other words, not only is feminism epistemologically structured out of resistance, and is thus in many ways a counter-discursive position, but in resignifying the referential fields of different backgrounds and historical experiences, it directly affects the change in power relations between the sexes in the social realm and theory, questioning authorities and transforming knowledge, creating and acting on critical knowledge. This brings into question not only the status of "agency" in theory but also works to (re)articulate theoretical concepts both for the self-authorisation and radicality of theory.

\begin{abstract}
What a pleasure it was to listen to philosophy in Women's Studies! I knew there was a different way of understanding the misogyny of philosophers like Hegel and Kant as well as the absence of women in philosophy. But I was missing the "key" to exposing this epistemic blindness. And myself in the theoretical chaos. Beauvoir - Wittig - Butler, how many inspiring thoughts, connections and important arguments! I felt it free from ideas (excerpt from an interview with a student generation, 2017/2018).
\end{abstract}

Therefore, when I think of feminist epistemology, I always think of both the extension and conversion of its meaning that in a parallel way signifies critical ways of knowledge, namely decolonising the self (Lugones, 2010) in terms of being free and being a part of the mutual decolonising of knowledge. In this regard, feminism(s) function(s) as many feminist theorists from Simone de Beauvoir to Audre Lorde, from Trinh Minhha to Maria Lugones, Nadežda Čačinovič and Chizuko Ueno imagined, as a kind of disobedience itself by opening up the long-running argument of theoretical "universality", by freeing language up from homogenous or gender-neutral interpretations or dismantling the objective grounds of truth, by enabling women to create their own spaces, epistemologically new ones, by subverting male-dominated discursive codes in order to save or create meanings of their own selves.

\title{
Feminist Classroom and Critical Pedagogy
}

How can we talk about feminism? How can we teach feminism and with which methodological and pedagogical tools? These questions are always in the midst of discussions among feminist scholars since the politics of knowledge is inseparable from the "politics of location" (Rich, 1986) as a signifying practice that grounds feminist theory in accountability for the situatedness of knowledge production. 
Throughout all these years, by creating a feminist classroom, different generations of students with their feminist teachers have demonstrated an almost impossible task: bringing together a rapidly changing student body and the more inclusive knowledge of feminist scholarship. Despite all the ongoing concerns around education and obstacles the Centre for Women's Studies has faced, there is still increasing student interest in attending the Centre's informal comprehensive I-year programme. From the very beginning, the Centre's students have had an opportunity to listen to feminist scholars and first-hand "activist" experiences of women from various women's groups and organisations, as well as from artists who have cooperated with the Centre on numerous occasions. During educational learning, students are encouraged to articulate their own voice and become aware of their own affinities, while witnessing how feminism can ensure another perspective for analysing different subjects as well as a space for dialogue. Along with the desire to gain feminist knowledge and its critical engaged drive, one of the motivations today is certainly their wish to contribute to the fight against endangering women's rights, injustice, discrimination as well as neoconservative, retrograde trends of misogyny and sexism.

The majority of the Centre's students have also seen this education as an opportunity to (de)construct subjectivities or create new ones based on feminist insights. In order to clarify the construction and deconstruction of gender in terms of understanding their meanings in the modern construction of the mind/nature frame and opening up to alternative subjectivities, Evelyn Fox Keller reminds us how "this method of feminist analysis is unquestionably powerful, but it is not always unproblematic" (Keller in de Lauretis,1986, p. 67).

Two difficulties spring to mind here: one is connected with the stubborn picture that relies on designed polarities (female/male images of genders and their archetypical myths), and the second one arises from the problem of acceptance gender variations or, as translated in contemporary discourse, "queering gender". Teaching "queering gender", for example, requires a fresh methodological approach for which the Centre, instead of being pedagogically well-prepared, offers a good theoretical and cultural analysis.

However, many students emphasised how this type of education was a way of enabling their personal transformation and growth. The following accounts of female students illustrate this:

I don't have a clear recollection of everything I listened to in the courses, but I know a transformation happened. I gradually became aware of 
some things. Words ceased to be ordinary information and became my own experience (excerpt from an interview with a student, 2017/2018 generation).

/.../ I noticed that after the Women's Studies programme I revised my basic views on society, on myself and my own choices, and on how I dared to say out loud some things I would never have dared to say before, that I was able to demand something, ask for something /.../ it was definitely a turning point in my education, if not in life itself /.../ (excerpt from an interview with a student generation, 2009/2010).

An important moment for a student's turning towards transformation, which on a personal level is often referred to as an act of articulation through voice, an act of self-awareness, self-knowledge or new knowledge, is part of the process in which knowledge of the self is contextualised, and in which woman is constituted as the subject of knowledge. Feminist positioning refers to two simultaneous inquiries: to articulation (Butler, 1997) through providing and creating stimulating, thoughtful, and provocative women's voices on diverse subjects from a woman's/gender perspective, and to "coming to voice", and both matter. Addressing voice as the place in one's own self where words have authority and by being recognisable - gain the recognition, "coming to voice" (Crary, 200I) refers to this very transformative momentum of shifting, a momentum of resistance where those who are marginalised become the agency of shifting events in favour of social change. While voicing, in a strictly Butlerian sense (Butler, 1997, p. 8), is an act of enactment, it can also be seen as an act of "ontological" solidarity with and among those who belong to similar subjugated or marginalised groups and communities. The process of self-reflection and articulation of knowledge through voicing and mutual listening defines the dynamic of educational practices themselves.

For me as a feminist who has been teaching feminist theories for more than two decades within both an alternative women's studies institution and within the university, critical pedagogy is an implicit avenue leading into feminist fields, almost its self-assumed presumption in the same manner as feminism is the self-critical process of re-reading and re-questioning theoretical areas, social reality and one's own position. More precisely, if the "/.../ challenge to scholars and social activists to push the boundaries of knowledge to go to new epistemological spaces", as clearly stated by Joe L. Kincheloe in his book Knowledge and Critical Pedagogy (Kincheloe 2008, p. 24), seems like a new demanding appeal nowadays, for feminists it has always been a way of thinking, breathing, feeling, existing, and disobeying hegemonic patterns of knowledge. Instead of an 
"epistemology of ignorance" that obscures, negates or distorts social realities (sex/gender realities, in particular) and its problems, several theorists (Boler \& Zembylas, 2002; Mignolo, 2007; Vargas, 2018, among others) developed the "epistemology of discomfort" as a counter-concept. Emerging from another ethics, it was the foundation for a "pedagogy of discomfort" which in the meantime became the basis for liberating ways of knowing. Although we have never actually so named the pedagogy that has been used in teaching Women's Studies, in many cases the practices have confirmed its use and validity.

The "pedagogy of discomfort" is briefly an explorative critical method and a tool for unfolding purported discomfort issues such as lesbian/ gay sexuality or sexual violence against women in order to understand the layers of obstacles, misunderstandings and the reasons for mimicry or silencing; or in order to see and act beyond the normal, namely, normative guidelines referring to hetero-normativism, beliefs or "habits of mind" linked to it. In other words, to see the world actively and consciously is to be made uncomfortable, if I follow this line of argument. According to Boler and Zembylas (2002, p. 2), this pedagogy engages students to enter into risky spaces of controversial ethical questions, calling them to critical awareness and action. Critical knowledge, according to them, is possible only in a "safe classroom" and by use of one's own emotional investment, when "collective witnessing" of experience creates a collective engagement which is recognised, known and felt.

On several occasions, I have faced this powerful momentum of collective awareness when violence against women was at stake, activating different aspects of personal and collective attachment, but also some very emotional breakdowns, intensified or unsolvable disputes among students. Nowadays, issues surrounding "sexual work" and prostitution signify such insurmountable controversy both among feminist scholars and students that it is unlikely to be resolved easily, if at all.

Nevertheless, liberating knowledge for feminists means not only making transparent all the models embedded in the relationship of subordination and domination, but a way to destabilise those relations or places that disenable a space for change by persevering on gender asymmetry and other epistemologically established power of matrice(s).

The education we are addressing here is always a project that deals both with the positional perspective that concerns women, gender, queer, or positional/political dimensions of one's own subjectivity as well as with the complexity of creative work in favour of social change, namely progressive social action. 


\section{Performing Feminism, Troubling Questions, Engaged Feminism}

What is an epistemologically reachable horizon when talking about the liberating of knowledge today? And, going back to Sternfeld's article and the timeless question: How can we radically change the circumstances from the inside? (Sternfeld, 2010, p. 5) These questions are somehow always on the feminist agenda, demanding very clear tasks from women's studies education. Education as a feminist (activist) project (Kašić, 2010) in the above-mentioned sense is the constant production of space(s) based on the principle of transversality that is created through the production of intersubjectivity, meetings, acts of experimenting, crossing over, new positioning and, on the other hand, seeking direct social engagement.

Before further elaborating on these issues, it is important to mention several obstacles that nowadays tend to block the politics of feminism as a liberating epistemology and/or engaged/activist theory. On one side, the politics of overgenderisation upon the feminist agenda that goes with the politics of gender mainstreaming as a rule exposed through "the politics of gender equality" holds the tendency for completely absorbing feminist content and disciplining and neutralising feminist critical demands. And yet a study presented in the article "Discursive Dynamics Gender Equality in Politics: What about 'Feminist Taboos'?" (Lombardo et al., 2010, pp. 105-124) shows how the application of the political concept of gender equality for more than a decade affects the process of depoliticising discourse on sex/gender issues and the scope of feminist engagement, and which has a direct impact on the production of feminist knowledge. Slovenian theorist Vlasta Jalušič significantly calls the implications of gender mainstreaming a process which, despite the initial intention, has directly produced "degendering" (Jalušič, 2009, p. 60). In academic institutions, it is obvious how the absence of the politicality of knowledge goes together with affirmation of the neutral categorical apparatus within the gender studies domain, and social sciences in particular. On the other side, there is the global commodification of knowledge which in a neo-global economy is encompassed in the "conflation of epistemic efficacy with pecuniary profitability" (Mirowski \& Sent, 2008), and for which neo-liberal narratives simultaneously produce competitive and expert-pragmatic knowledge often in the function of capitalist exploitation and financialisation. As a consequence, the problematic topoi of modern slavery, taking this as an example, marked by sex/gender and migrants of various kinds, human humiliation or the feminisation of poverty, enters into the array of educational interest only as an articulation of difference which, instead of a critical insight, is merely exoticised or trivialised. 
Of course, critical knowledge that engages feminist, antiracist or anti-colonial voices has nothing to do with this and accordingly is often marginalised within leading mainstream studies on projective streams towards globalisation.

Thus Judith Butler pointed out that:

It may be that knowledge will begin even more radically to circulate outside the university, and though there are many reasons to wish for the displacement of the university as the center of knowledge, it would be an unimaginable loss for the university /.../ (Butler, 2013, p. 190).

Along with the above-mentioned obstacles, there has been, according to Chandra Talpade Mohanty, the development of a "careerist academic feminism" in which feminism has become a way of advancing individual careers rather than a call for collective activism or radical transformation (Mohanty, 2003, p. 6). Do we still cultivate a politics of solidarity among feminist scholars and feminists in general as grounds for a feminist agenda, or is there no obligation beyond our professional positions and properly designed academic curricula?

In order to claim feminist alliances, we should rely on the places still left, or new ones that would enable a creative and critical feminist crossing. And yet, viewing the world today, the questions are becoming more layered and complex, and key feminist dilemmas by gaining new contours are becoming ever sharpened, and the feminist struggle more arduous.

A WS student recently asked me how to deal with "capitalist feminism". Although confused momentarily by this unusual question because it seems that everything is receiving a soft-fluid capitalist attribution and coating in a global world characterised by new-capitalist expansions, I quickly responded with a counter-question: "How to fight capitalism with feminist tools?". At that moment, I did not want to jump into an elaboration of the discursive paradox based on the very incommensurability between capitalism and feminism. Instead, I tried to make my arguments around the contemporary capitalist "empire" as a masculinist project and its global corporate brotherhood. The effects of global capital production directly attack women, making them disposable and cheap labour in order to make a profit (Gržinić, 2009). Not only is any pact that enables the continuity of modes of capitalist production founded on the division of labour and, in this regard, over-exploited female workers in the status of "modern slaves", but the exclusion of women as potential agency in this pact is conditio sine qua non of any capital logic and existence. These days where co-propriety between capital and power, working closely both nationally and internationally, functions "efficiently" by multiplying 
profits on the subjugation and exploitation of human lives and devastation of the human environment, feminist engagement in its acts must undergo a radical re-adjustment (Spivak, 20I2) and transformative process.

In one of her articles against the threatening conjunction of feminism and capitalism, Nancy Fraser (2013) draws attention to unfolding the three contributions of feminism to neoliberal development. First, by insisting on the goods of individual advancement, increased choices and family wage, feminism has in fact helped with "flexible capitalism", its decreasing job security, precarity and low-waged work, and female-headed households. Second, by turning to identity politics and sexism, "politicizing the personal" and "rejecting economism" (ibid., 2013), feminism coincides with the rising neoliberalism that is repressing both social equality and all memory of social equality. Third, by its continuous critique of welfare-state paternalism, feminism has contributed to free-market (corporate/financial) fundamentalism (via micro credits, among others), which adds extremely to inequality and poverty, especially among women.

It is therefore no coincidence that Marxist feminism has become all the more the domain for exploration in the Centre's programme, and shaped its syllabuses in the last few years. At the same time, it has become a place of confusion and often misunderstanding since the Centre's educators have not as a rule theoretically articulated this issue (Marxist political economy, precisely), or been deeply tempted by more specific economic inquiries that come out of neoliberal social realm(s). Since the programme has been shaped more around the interests of both scholars and students, mainly at the crossroads of cultural studies and feminist activism in a wider sense, but against violence against women in particular, and philosophical entries into the many venues of feminist knowledge, there are new challenging concerns that must be discussed. Besides the problematic points around "queering gender" and how it resonates with lesbian issues, women-oriented agenda or patriarchy, for example, there are fresh troubling questions that need to be answered.

How can we confront commodity feminism? How can we fight celebrity-branded feminism in which the voices of women emanate from the celebrity machine based on generally unquestioned gender/sex inequality? Or, how can we create feminist explanatory models that effectively resist women's job precarity are but some of these questions.

In this regard, a fruitful point of departure for feminism as critical agency right now might involve how we can articulate the importance of a subjugated perspective in rethinking the conceptual educational framework behind the dominant practices (economic/political/cultural), if I try to rephrase Kincheloe's concern (Kincheloe, 2008, p. 53), and at the 
same time how to enable feminists in performing engaged theory toward a just and equal society without the burden of the many emerging conflicting positionalities that contaminate feminist alliances. Are we ready for it?

\section{References}

Alvanoudi, A. (2009). Teaching Gender in the Neoliberal University. In D. Gronold, B. Hipfl, \& L. L. Pedersen (Eds.), Teaching with the Third Wave New Feminists' Explorations of Teaching and Institutional Contexts. Teaching with Gender. European Women's Studies in International and Interdisciplinary Classrooms (pp. 37-54). ATHENA.

Barada, V., Janušić, J., Kašić, B., \& Pešut, J. (2003). Institucionalizacija ženskih studija u Hrvatskoj - akcijsko istraživanje. Centar za ženske studije.

Bahovec, E. (2002). Feminizam kao epistemologijski projekt, Zarez, 4(80), 23. Retrieved February 5, 2020 , from https://bib.irb.hr/datote$\mathrm{ka} / 838442.080 . p d f$.

Butler, J. (1997). Excitable Speech: A Politics of the Performative. Routledge.

Butler, J., \& Athanasiou, A. (2013). Dispossession: The Performative in the Political. Polity Press.

Cornell, D. (1995). Rethinking the Time of Feminism. In S. Benhabib, J. Butler \& D. Cornell, Feminist Contentions: A Philosophical Exchange (pp. I45-157). Routledge.

Crary, A. (200I). A Question of Silence: Feminist Theory and Women's Voices, Philosophy, 76(297), 371-395.

Čakardić, A., Borić, R., Govedić, N., Kašić, B., Sibila, I. N., \& Simonović, K. (2010). Privilegiranje rubova: intervencije i prilozi feminističkoj epistemologiji. Centar za ženske studije \& Hrvatsko filozofsko društvo.

de Lauretis, T. (Ed). (1986). Feminist Studies/Critical Studies. Indiana University Press.

Evans, M. (2003). Killing Thinking: The Death of the Universities. Continuum.

Fraser, N. (2013). How feminism became capitalism's handmaiden - and how to reclaim it. Retrieved May I2, 2020, from https://www.theguardian.com/commentisfree/2013/oct/r4/ feminism-capitalist-handmaiden-neoliberal.

Gill, R. (2007). Postfeminist media culture: Elements of a sensibility. European Journal of Cultural Studies. Retrieved March 13, 2020, from https://doi.org/10.1177/1367549407075898. 
Gržinić, M. (2009). Capital, Repetition. Reartikulacija (16. December 2009), 8, 3-4.

Harding, S. G. (Ed.) (2004). The Feminist Standpoint Theory Reader: Intellectual and Political Controversies. Routledge.

Hemmings, C. (2008). Tunning Problems? Notes on Women's and Gender Studies and the Bologna Process, European Journal of Women's Studies, IS (2), I7-I27.

Hill Collins, P. (2009). Black feminist thought: knowledge, consciousness, and the politics of empowerment. Routledge.

hooks, b. (1996). Choosing the Margin as a Space of Radical Openness. In A. Garry \& M. Pearsall (Eds.), Women, Knowledge, and Reality. Explorations in Feminist Philosophy (pp. 48-57). Routledge.

Jalušič, V. (2009). Stretching and Bending the Meanings of Gender in Equality Politics. In E. Lombardo, P. Meier \& M. Verloo (Eds.), The Discursive Politics of Gender Equality: Stretching, Bending and Policymaking (pp. 52-67). Routledge.

Kašić, B. (20IO). Feminističke teze o prijestupima radikalnosti i politici spoznaje. In A. Čakardić, R. Borić, N. Govedić, B. Kašić, I. N. Sibila \& K. Simonović (Eds.), Privilegiranje rubova: intervencije i prilozi feminističkojepistemologiji (pp. I 4I-I73). Centar za ženske studije \& Hrvatsko filozofsko društvo.

Kašić, B. (2011). Feministička intelektualna klasa: Zebnje oko integracije ipolitika spoznavanja. In I. Radačić \& J. Vince Pallua (Eds.), Ljudska prava žena (pp.167-185). Institut društvenih znanosti Ivo Pilar.

Kašić, B. (2016). “Unsettling” women’s studies, settling neoliberal threats in the academia: A feminist gaze from Croatia. Women's Studies International Forum, 54, I29-137.

Keller, E. F. (1986). Making Gender Visible in the Pursuit of Nature's Secret. In T. de Lauretis (Ed.), Feminist Studies/Critical Studies (pp. 67-77). Indiana University Press.

Kincheloe, J. L. (2008). Knowledge and Critical Pedagogy: An Introduction. Springer.

Liinason, M., \& Holm, U. (2006). PhD's, Women's/Gender Studies and Interdisciplinarity. NORA - Nordic Journal of Feminist and Gender Research, I4(2), II5-I3O.

Lombardo, E., Meier, P., \& Verloo, M. (2010). Discursive Dynamics in Gender Equality Politics: What about "Feminist Taboos"? European Journal of Women's Studies, I7(2), 105-I24. 
Lugones, M. (2010). Toward a Decolonial Feminism. Hypatia, 25(4), $742-759$.

Mohanty, Ch. T. (2003). Feminism without Borders, Decolonizing Theory, Practicing Solidarity. Duke University Press.

Mirowski, P., \& Sent, E. M. (2008). The Commercialization of Science and the Response of STS. In E. J. Hackett, O. Amsterdamska, M. E. Lynch, \& J. Wajcman (Eds.), Handbook of Science and Technology Studies $\left(3^{\text {rd }} \mathrm{ed}\right)$ (pp. 635-689). MIT Press.

Mignolo, W. D. (2007). Coloniality of power and de-colonial thinking. Retrieved June 23, 2020, from https:/www.tandfonline.com/doi/ full/10.1080/09502380601162498.

Pereira, M. do M. (2017). Power, Knowledge and Feminist Scholarship. An Ethnography of Academia. Routledge.

Prügl, E. (2015). Neoliberalising Feminism. New Political Economy, 2o(4), 6I4-63I.

Rich, A. (1986). Blood, Bread, and Poetry: Selected Prose, 1979-1985. Norton.

Smith, D. E. (1987). The Everyday World as Problematic: A Feminist Sociology. Northeastern University Press.

Spivak, G. Ch. (2012). An Aesthetic Education in the Era of Globalization. Harvard University Press.

Sternfeld, N. (2010). Unglamorous Tasks: What Can Education Learn from its Political Traditions?, Journal \#1 4, e-flux. Retrieved May 20, 2020, from https://www.e-flux.com/journal/14/61302/unglamorous-tasks-what-can-education-learn-from-its-political-traditions/.

Squires, J. (2005). Is Mainstreaming Transformative? Theorizing Mainstreaming in the Context of Diversity and Deliberation Social Politics. International Studies in Gender, State \& Society, I2(3), 366-388.

Vargas, V. (2018). Women's Place in the Andes: Engaging Decolonial Feminist Anthropology (First ed.). University of California Press.

Zembylas, M., \& Boler, M. (2002). On the Spirit of Patriotism: Challenges of a "Pedagogy of Discomfort". Teachers College Record. Retrieved June 6, 2020, from https: //meganboler.files.wordpress.com/2016/o2/on_ the_spirit_of_patriotism_challenges_o.pdf, I-27. 